\title{
Serum IgG4 Levels at Diagnosis Can Predict Unfavorable Outcomes of Untreated Patients With IgG4-related Disease: A Japanese Single-Center Retrospective Study
}

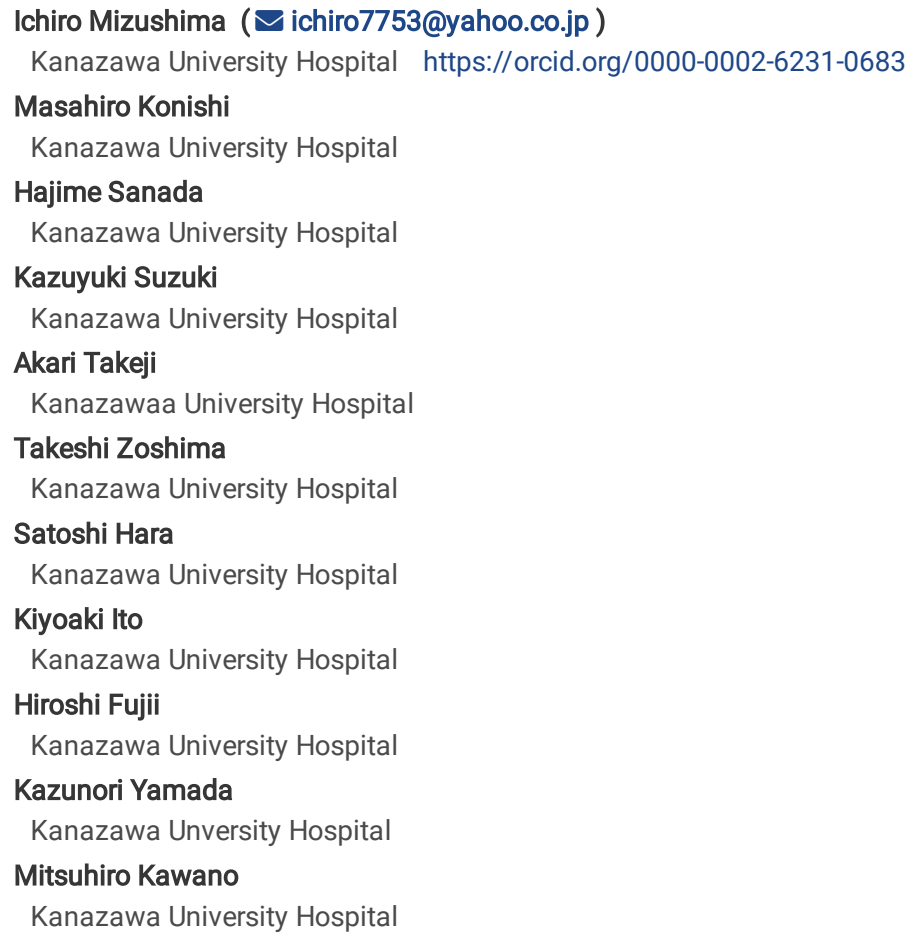




\section{Abstract \\ Background}

The outcomes of patients with IgG4-RD who are not treated are unclear. This study aimed to clarify these outcomes and identify the factors related to them.

\section{Methods}

We retrospectively evaluated various clinical features including laboratory data and involved organs at diagnosis in 107 patients with IgG4-RD, who were followed up for more than 6 months, at a single center in Japan. We compared the clinical features of the 27 untreated patients with those of the 80 patients treated with glucocorticoid. The patient outcomes were investigated, and logistic regression analysis was performed to identify factors related to them.

\section{Results}

The patients comprised 73 men and 34 women (median age 67 years). The untreated patients had significantly lower IgG4-RD responder index ( 9 vs 12 ) and fewer affected organs ( 1 vs 3 ) than did those treated with glucocorticoid. Of these 27 patients, 8 experienced deterioration of IgG4-RD after the diagnosis. In the age- and sex-adjusted logistic regression analysis, serum IgG4 elevation (per $100 \mathrm{mg} / \mathrm{dL}$, odds ratio 1.194, 95\% confidence interval 1.017-1.402) was the only significant factor related to disease deterioration in untreated patients with lgG4-RD, whereas not serum IgG4 levels (per $100 \mathrm{mg} / \mathrm{dL}$, odds ratio 0.995 , $95 \%$ confidence interval $0.921-1.075$ ) but history of allergy (OR $3.134,95 \%$ confidence interval $1.094-8.977, \mathrm{P}=0.033$ ) related to deterioration in patients who underwent treatment.

\section{Conclusions}

Serum IgG4 levels may be a useful predictor of unfavorable outcomes in untreated patients with IgG4-RD, who tend to have fewer affected organs and lower IgG4-RD responder index.

\section{Background}

Immunoglobulin G4 (IgG4)-related disease (IgG4-RD) is a systemic fibro-inflammatory disease that can affect almost all organs of the body [1, 2]. In IgG4-RD, spontaneous, or at least temporary, remissions without treatment have been reported, and watchful waiting may be appropriate in certain patients with asymptomatic and inactive disease [3].

Indeed, in type 1 autoimmune pancreatitis (AIP), it was reported that spontaneous remissions (SR) without treatment were observed in 55.7-65.0\% of patients $[4,5]$. The suggested predictors for SR included absence of serum IgG4 elevation, female gender, and stent placement for jaundice. On the other hand, unfavorable events including symptomatic, radiological, or functional exacerbation of the organ involved or relapse occurred in 50-70\% of AIP patients without treatment $[5,6]$. New onset of diabetes mellitus and extensive multi-organ involvement were reported as predictors for unfavorable events in untreated patients [5].

However, the outcomes of patients with IgG4-RD, especially those except for AIP, who do not undergo treatment are still unclear. This state of affairs prompted us to undertake the present study to clarify the outcomes of untreated patients with IgG4-RD and the factors related to them.

\section{Methods}

\section{Patients and Materials}

We included 107 consecutive patients diagnosed with IgG4-RD between January 1, 2004, and December 31, 2017, who were followed-up for more than 6 months, at a single center in Japan. The diagnosis of IgG4-RD was made based on their fulfillment of the published comprehensive diagnostic criteria (CDC) [7] or each set of organ-specific diagnostic criteria [8-10] and exclusion of other diseases. Twenty-seven of these patients were followed up without treatment after the initial diagnosis. The following clinical factors at the time of diagnosis were retrospectively determined: age; gender; history of allergy; serum levels of IgG, IgG4, IgE, C3, C4, CH50, C-reactive protein (CRP), and creatinine; peripheral blood eosinophil counts; presence of rheumatoid factor (RF) and antinuclear antibodies (ANA); number of affected organs; involvement of pancreas, salivary glands, ophthalmus, kidney, aorta/artery, retroperitoneum, and lung; IgG4-RD responder index. We compared the clinical features of these 27 patients with those of the 80 patients who underwent treatment. In addition, the patient outcomes were investigated, and logistic regression analysis was performed to assess factors related to the outcomes.

Deterioration of IgG4-RD was defined as symptomatic, radiological, or functional exacerbation of the organ involved or de novo organ involvement. Spontaneous improvement (SI) of IgG4-RD was defined as symptomatic, radiological, or functional improvement of more than one of the organs involved and absence of deterioration as defined above in untreated patients.

This study received institutional ethics board approval from the Medical Ethics Committee of Kanazawa University, and informed consent for the use of all data and samples was obtained from each patient. We conducted the research in compliance with the Declaration of Helsinki.

\section{Statistical Analysis}


Statistical analysis was performed using SPSS V.25. Data are presented as median [interquartile range (IQR1, IQR3)] for continuous variables. The significance of differences between groups was determined using Mann-Whitney $U$ test, while that of differences in frequencies was analyzed with Fisher's exact probability test. For assessment of factors related to SI or deterioration of IgG4-RD during observation periods, unadjusted and age- and sex-adjusted logistic regression analyses were performed. Because SI or deterioration could frequently be detected only on imaging examinations, which were not always performed at frequent or regular intervals in this retrospective study, a time-to-event analysis such as Cox regression analysis was not used. In these logistic

regression analyses, for continuous variables, unit for increments to calculate odds ratios were set at 1 year for age; $100 \mathrm{mg} / \mathrm{dL}$ for serum IgG4 and lgG levels; $100 \mathrm{IU} / \mathrm{mL}$ for serum IgE levels; $1 \mathrm{U} / \mathrm{mL}$ for serum CH50 levels; $1 \mathrm{mg} / \mathrm{dL}$ for serum C3, C4, CRP, and creatinine levels; $100 / \mu \mathrm{L}$ for eosinophil counts. Significant differences were defined as $P<0.05$.

\section{Results}

\section{Baseline Patient Profiles}

The profiles of the 107 IgG4-RD patients are listed in Table 1. The median follow-up period after the start of therapy or observation without therapy was 63 months [interquartile range (IQR) 25, 85]. At diagnosis, their median serum IgG4 level was $486 \mathrm{mg} / \mathrm{dL}$ (IQR 220, 991). Involvement of the salivary gland was observed in $58 \%$ of patients, eye in $47 \%$, pancreas in $26 \%$, perivasculature in $27 \%$, kidney in $21 \%$, lung in $25 \%$, and retroperitoneum in $8 \%$. Twenty-seven patients were followed up without treatment after the initial diagnosis according to the decision of each attending physician. Compared with the 80 patients with treatment, these 27 patients had a significantly lower IgG4-RD responder index $[9(6,15)$ vs $12(9,18), P=0.048]$, fewer affected organs $[1(1,3)$ vs $3(2$, $4), P=0.001]$, and lower frequency of ophthalmic and renal parenchymal lesions ( $26 \%$ vs $54 \%, P=0.015$, and $4 \%$ vs $26 \%, P=0.012$, respectively). 
Table 1

Baseline Clinical Characteristics of 107 Patients with IgG4-Related Disease

\begin{tabular}{|c|c|c|c|c|}
\hline & Overall & Treatment & & \\
\hline & \multirow[t]{2}{*}{$n=107$} & $(-)$ & \multicolumn{2}{|l|}{$(+)$} \\
\hline & & $n=27$ & $\mathrm{n}=80$ & $P$-value \\
\hline Age & $67(59,73)$ & $70(60,78)$ & $66(59,72)$ & 0.144 \\
\hline Male gender (\%) & 68 & 78 & 65 & 0.243 \\
\hline Allergy (\%) & 56 & 70 & 51 & 0.116 \\
\hline Serum IgG4 level (mg/dL) & $486(220,991)$ & $361(187,1,040)$ & $495(254,975)$ & 0.507 \\
\hline Serum IgG level (mg/dL) & $1,951(1,531,2,872)$ & $1,960(1,512,2,655)$ & $1,950(1,535,2,936)$ & 0.637 \\
\hline Serum IgE level (IU/mL) & $486(190,1,231)$ & $755(122,1,764)$ & $474(235,1,036)$ & 0.670 \\
\hline Serum C3 level (mg/dL) & $90(76,110)$ & $90(76,106)$ & $94(76,110)$ & 0.810 \\
\hline Serum C4 level (mg/dL) & $22(14,27)$ & $22(19,28)$ & $21(14,27)$ & 0.363 \\
\hline Serum CH50 level (IU/L) & $51(38,58)$ & $50(39,56)$ & $51(35,59)$ & 0.976 \\
\hline Serum CRP level (mg/dL) & $0.1(0.0,0.3)$ & $0.1(0.0,0.2)$ & $0.1(0.0,0.3)$ & 0.599 \\
\hline Serum creatinine level (mg/dL) & $0.79(0.64,1.00)$ & $0.75(0.65,0.94)$ & $0.80(0.60,1.05)$ & 0.415 \\
\hline Eosinophil count $(/ \mu \mathrm{L})$ & $204(118,426)$ & $180(119,598)$ & $230(118,422)$ & 0.766 \\
\hline RF positivity (\%) & 20 & 17 & 21 & 0.772 \\
\hline ANA positivity (\%) & 14 & 11 & 15 & 0.755 \\
\hline Pancreatic lesion (\%) & 26 & 19 & 29 & 0.448 \\
\hline Salivary gland lesion (\%) & 58 & 67 & 55 & 0.369 \\
\hline Ophthalmic lesion (\%) & 47 & 26 & 54 & 0.015 \\
\hline Renal lesion (\%) & 21 & 4 & 26 & 0.012 \\
\hline Vascular lesion (\%) & 27 & 30 & 26 & 0.804 \\
\hline Retroperitoneal lesion (\%) & 8 & 4 & 10 & 0.444 \\
\hline Lung lesion (\%) & 25 & 11 & 30 & 0.072 \\
\hline Number of involved organs & $2(1,4)$ & $1(1,3)$ & $3(2,4)$ & 0.001 \\
\hline IgG4-RD responder index & $12(9,18)$ & $9(6,15)$ & $12(9,18)$ & 0.048 \\
\hline \multicolumn{5}{|c|}{ Note: Conversion factor for $\mathrm{Cr}: \mathrm{mg} / \mathrm{dL}$ to $\mu \mathrm{mol} / \mathrm{L}, \times 88.4$. Data are presented as median [interquartile range (IQR1, IQR3)]. } \\
\hline $\begin{array}{l}\text { Abbreviations: ANA, anti-nuclea } \\
\text { disease; IgE, immunoglobulin } \mathrm{E} \text {; }\end{array}$ & $\begin{array}{l}\text { C-reactive protein; Ig } \\
\text { one; } \mathrm{RF} \text {, rheumatoid } \mathrm{f}\end{array}$ & oglobulin G; IgG4, imm & lin G4; IgG4-RD, immı & G4-relate \\
\hline
\end{tabular}

During the clinical course, 6 of the 27 untreated patients experienced SI (Table 2). Renal pelvic lesion improved spontaneously in 2 patients, and lacrimal gland lesion, submandibular gland lesion, pancreas, retroperitoneum, and periaortic lesion in one each. In the age- and sex-adjusted logistic regression analysis, male gender [vs. female, odds ratio (OR) 0.064, 95\% confidence interval (Cl) 0.006-0.644, $\mathrm{P}=0.020$ ] and serum $\mathrm{C} 3$ levels $(\mathrm{OR} 1.090,95 \% \mathrm{Cl} 1.005-$ $1.182, P=0.039)$ were significant factors related to $S I$ in untreated patients with IgG4-RD (Table 3 ). 
Table 2

Baseline Clinical Data of 27 Untreated Patients with IgG4-Related Disease

\begin{tabular}{|c|c|c|c|c|c|c|c|c|c|c|c|}
\hline No. & $\begin{array}{l}\operatorname{lgG4} \\
(\mathrm{mg} / \mathrm{dL})\end{array}$ & $\begin{array}{l}\lg G \\
(\mathrm{mg} / \mathrm{dL})\end{array}$ & $\underset{(\mathrm{IgE}}{\lg / \mathrm{mL})}$ & Hypocomplementemia & $\begin{array}{l}\text { Eosinophil } \\
\text { count }(/ \\
\mu L)\end{array}$ & Allergy & $\begin{array}{l}\text { Involved } \\
\text { organs }\end{array}$ & $\begin{array}{l}\text { Number } \\
\text { of } \\
\text { involved } \\
\text { organs }\end{array}$ & $\begin{array}{l}\text { lgG4- } \\
\text { RD } \\
\text { RI }\end{array}$ & $\begin{array}{l}\text { Spontaneous } \\
\text { improvement }\end{array}$ & Deterioration \\
\hline 1 & 164 & 1960 & 1621 & - & 197 & + & $\mathrm{Sa}, \mathrm{La}$ & 2 & 9 & - & - \\
\hline 2 & 2150 & 3310 & 74 & - & 177 & + & $\begin{array}{l}\text { Sa, La, } \\
\text { K }\end{array}$ & 3 & 12 & + & + \\
\hline 3 & 354 & 1963 & 764 & - & 138 & - & $A$ & 1 & 9 & - & - \\
\hline 4 & 196 & 1487 & 447 & - & 191 & + & $A, R F$ & 2 & 15 & + & - \\
\hline 5 & 187 & 1317 & 134 & - & 21 & + & $\mathrm{Sa}, \mathrm{La}$ & 2 & 9 & + & - \\
\hline 6 & 73.1 & 1277 & 49 & - & 180 & + & $\mathrm{Sa}$ & 1 & 3 & - & - \\
\hline 7 & 1230 & 2655 & 1668 & - & 1014 & + & $\begin{array}{l}\text { Sa, K, L, } \\
\text { S }\end{array}$ & 4 & 18 & - & - \\
\hline 8 & 565 & 1732 & 135 & - & 113 & + & $\mathrm{P}$ & 1 & 12 & - & - \\
\hline 9 & 2150 & 3751 & 4423 & - & 149 & + & $\mathrm{Sa}$ & 1 & 9 & - & - \\
\hline 10 & 1520 & 2938 & 48 & - & 79 & - & $\mathrm{Sa}$ & 1 & 6 & - & + \\
\hline 11 & 361 & 1936 & 8 & + & 119 & - & Sa, Ly & 2 & 9 & - & + \\
\hline 12 & 1040 & 2127 & 227 & - & 249 & - & $\begin{array}{l}\mathrm{Sa}, \mathrm{A} \\
\mathrm{Ph}\end{array}$ & 3 & 15 & - & + \\
\hline 13 & 632 & 1934 & 328 & - & 70 & + & $\mathrm{La}$ & 1 & 6 & - & - \\
\hline 14 & 997 & 2078.7 & 1730 & - & 150 & - & $\mathrm{A}, \mathrm{Bi}$ & 2 & 15 & - & + \\
\hline 15 & 254 & 1559.6 & 745 & - & 290 & - & $\begin{array}{l}\text { Sa, La, } \\
\text { L, Ly }\end{array}$ & 4 & 15 & - & - \\
\hline 16 & 374 & 1413.9 & 883 & - & 180 & + & $\mathrm{K}$ & 1 & 6 & - & - \\
\hline 17 & 1160 & 3506 & 2328 & - & 68 & + & $\mathrm{L}$ & 1 & 18 & - & + \\
\hline 18 & 1740 & 4298 & 324 & - & 959 & + & $\mathrm{Sa}$ & 1 & 15 & - & + \\
\hline 19 & 292 & 2141 & 87 & - & 362 & - & $\mathrm{P}$ & 1 & 6 & - & - \\
\hline 20 & 313 & 2237 & 1867 & - & 70 & - & $\begin{array}{l}\text { Sa, La, } \\
\text { A, Ly, } \\
\text { Pec }\end{array}$ & 5 & 24 & + & - \\
\hline 21 & 534 & 1674 & 86 & - & 598 & + & $\begin{array}{l}\text { Sa, La, } \\
\mathrm{P}, \mathrm{K}\end{array}$ & 4 & 15 & + & - \\
\hline 22 & 136 & 1419 & 1247 & - & 188 & + & $\mathrm{Sa}$ & 1 & 6 & - & - \\
\hline 23 & 133 & 983 & 1364 & - & 829 & + & $\mathrm{Sa}$ & 1 & 3 & - & - \\
\hline 24 & 185 & 1924 & 32313 & - & 2952 & + & $\mathrm{Sa}$ & 1 & 6 & - & - \\
\hline 25 & 297 & 2213 & 2042 & - & 772 & + & Sa, P, K & 3 & 12 & - & - \\
\hline 26 & 99.8 & 1512 & NA & - & 121 & + & $\mathrm{Bi}$ & 1 & 6 & + & + \\
\hline 27 & 969 & 3635 & 4042 & - & 2262 & + & $\mathrm{K}, \mathrm{Bi}$ & 2 & 12 & - & - \\
\hline
\end{tabular}


Table 3

Odds ratio for risk of spontaneous improvement of IgG4-RD: unadjusted and age- and sex-adjusted logistic regressions

\begin{tabular}{|c|c|c|c|c|c|c|}
\hline \multirow[t]{3}{*}{ Variable } & \multicolumn{6}{|c|}{ Untreated Patients } \\
\hline & \multicolumn{3}{|c|}{ Unadjusted } & \multicolumn{3}{|c|}{ Age- and Sex-Adjusted } \\
\hline & OR & $95 \% \mathrm{Cl}$ & P-value & OR & $95 \% \mathrm{Cl}$ & P-value \\
\hline Age (years) & 0.943 & 0.869 to 1.024 & 0.161 & 0.973 & 0.886 to 1.069 & 0.574 \\
\hline Male gender & 0.053 & 0.006 to 0.493 & 0.010 & 0.064 & 0.006 to 0.644 & 0.020 \\
\hline Allergy & 2.500 & 0.243 to 25.717 & 0.441 & 1.490 & 0.092 to 24.090 & 0.779 \\
\hline Serum IgG4 level (100 mg/dL) & 0.967 & 0.825 to 1.135 & 0.684 & 0.967 & 0.806 to 1.160 & 0.718 \\
\hline Serum IgG level (100 mg/dL) & 0.946 & 0.831 to 1.077 & 0.399 & 0.966 & 0.826 to 1.131 & 0.667 \\
\hline Serum IgE level (100 IU/mL) & 0.925 & 0.804 to 1.064 & 0.276 & 0.991 & 0.921 to 1.066 & 0.807 \\
\hline Serum C3 level (mg/dL) & 1.053 & 1.004 to 1.106 & 0.035 & 1.090 & 1.005 to 1.182 & 0.039 \\
\hline Serum C4 level (mg/dL) & 1.024 & 0.936 to 1.119 & 0.607 & 1.105 & 0.960 to 1.272 & 0.163 \\
\hline Serum CH50 level (IU/L) & 1.055 & 0.965 to 1.153 & 0.243 & 1.117 & 0.968 to 1.290 & 0.130 \\
\hline Serum CRP level (mg/dL) & 1.299 & 0.069 to 24.497 & 0.861 & 6.467 & 0.245 to 170.80 & 0.264 \\
\hline Serum Cr level (mg/dL) & 0.021 & 0.000 to 6.486 & 0.186 & 7.379 & 0.024 to 2247.9 & 0.493 \\
\hline Eosinophil counts $(100 / \mu \mathrm{L})$ & 0.813 & 0.532 to 1.242 & 0.338 & 0.821 & 0.462 to 1.457 & 0.499 \\
\hline Number of involved organs & 2.173 & 0.988 to 4.775 & 0.053 & 1.925 & 0.746 to 4.918 & 0.176 \\
\hline IgG4-RD responder index & 1.147 & 0.949 to 1.388 & 0.156 & 1.222 & 0.942 to 1.584 & 0.130 \\
\hline \multicolumn{7}{|c|}{ Note: Conversion factor for $\mathrm{Cr}: \mathrm{mg} / \mathrm{dL}$ to $\mu \mathrm{mol} / \mathrm{L}, \times 88.4$. } \\
\hline
\end{tabular}

Of the 27 untreated patients, 8 experienced deterioration of IgG4-RD 37.5 (IQR 14.5, 81.5) months after the diagnosis (Table 2). De novo organ involvement was observed in all 8 patients, 2 of whom concurrently suffered exacerbation of the organs involved. Of the 80 treated patients, 25 experienced deterioration of IgG4-RD 31 (IQR 13, 63) months after the diagnosis. In the age- and sex-adjusted logistic regression analysis, serum IgG4 elevation (per 100 mg/dL, OR $1.194,95 \% \mathrm{Cl} 1.017-1.402, \mathrm{P}=0.030$ ) was the only significant factor related to disease deterioration in untreated patients with IgG4-RD, whereas serum IgG4 levels did not relate to deterioration in patients who underwent treatment (per $100 \mathrm{mg} / \mathrm{dL}, \mathrm{OR} 0.995,95 \% \mathrm{Cl} 0.921-1.075, \mathrm{P}=0.901$ ). On the other hand, history of allergy (OR 3.134, 95\% Cl 1.094-8.977, P = 0.033) was the only significant factor related to deterioration of disease in treated patients with IgG4-RD (Table 4). 
Table 4

Odds ratio for risk of deterioration of IgG4-RD: unadjusted and age- and sex-adjusted logistic regressions

\begin{tabular}{|c|c|c|c|c|c|c|c|c|c|c|c|c|}
\hline \multirow[t]{3}{*}{ Variable } & \multicolumn{6}{|c|}{ Untreated Patients } & \multicolumn{6}{|c|}{ Treated Patients } \\
\hline & \multicolumn{3}{|c|}{ Unadjusted } & \multicolumn{3}{|c|}{ Age- and Sex-Adjusted } & \multicolumn{3}{|c|}{ Unadjusted } & \multicolumn{3}{|c|}{ Age- and Sex-Adjusted } \\
\hline & OR & $95 \% \mathrm{Cl}$ & $\begin{array}{l}\mathrm{P} \text { - } \\
\text { value }\end{array}$ & OR & $95 \% \mathrm{Cl}$ & $\begin{array}{l}\mathrm{P} \text { - } \\
\text { value }\end{array}$ & OR & $95 \% \mathrm{Cl}$ & $\begin{array}{l}\mathrm{P} \text { - } \\
\text { value }\end{array}$ & OR & $95 \% \mathrm{Cl}$ & $\begin{array}{l}P \text { - } \\
\text { value }\end{array}$ \\
\hline Age (years) & 1.051 & $\begin{array}{l}0.966 \text { to } \\
1.143\end{array}$ & 0.251 & 1.047 & $\begin{array}{l}0.958 \text { to } \\
1.143\end{array}$ & 0.314 & 0.960 & $\begin{array}{l}0.916 \text { to } \\
1.007\end{array}$ & 0.098 & 0.964 & $\begin{array}{l}0.918 \text { to } \\
1.012\end{array}$ & 0.140 \\
\hline Male gender & 2.500 & $\begin{array}{l}0.243 \text { to } \\
25.717\end{array}$ & 0.441 & 1.871 & $\begin{array}{l}0.166 \text { to } \\
21.054\end{array}$ & 0.612 & 0.569 & $\begin{array}{l}0.215 \text { to } \\
1.510\end{array}$ & 0.258 & 0.655 & $\begin{array}{l}0.240 \text { to } \\
1.789\end{array}$ & 0.409 \\
\hline Allergy & 0.342 & $\begin{array}{l}0.076 \text { to } \\
1.532\end{array}$ & 0.161 & 0.310 & $\begin{array}{l}0.051 \text { to } \\
1.877\end{array}$ & 0.202 & 3.578 & $\begin{array}{l}1.284 \text { to } \\
9.965\end{array}$ & 0.015 & 3.134 & $\begin{array}{l}1.094 \text { to } \\
8.977\end{array}$ & 0.033 \\
\hline $\begin{array}{l}\text { Serum IgG4 level (100 } \\
\mathrm{mg} / \mathrm{dL})\end{array}$ & 1.197 & $\begin{array}{l}1.021 \text { to } \\
1.404\end{array}$ & 0.027 & 1.194 & $\begin{array}{l}1.017 \text { to } \\
1.402\end{array}$ & 0.030 & 0.989 & $\begin{array}{l}0.916 \text { to } \\
1.067\end{array}$ & 0.766 & 0.995 & $\begin{array}{l}0.921 \text { to } \\
1.075\end{array}$ & 0.901 \\
\hline $\begin{array}{l}\text { Serum IgG level (100 } \\
\mathrm{mg} / \mathrm{dL})\end{array}$ & 1.113 & $\begin{array}{l}0.999 \text { to } \\
1.239\end{array}$ & 0.052 & 1.104 & $\begin{array}{l}0.987 \text { to } \\
1.236\end{array}$ & 0.084 & 1.007 & $\begin{array}{l}0.966 \text { to } \\
1.050\end{array}$ & 0.734 & 1.020 & $\begin{array}{l}0.976 \text { to } \\
1.066\end{array}$ & 0.378 \\
\hline $\begin{array}{l}\text { Serum IgE level (100 } \\
\text { IU } / \mathrm{mL})\end{array}$ & 0.951 & $\begin{array}{l}0.861 \text { to } \\
1.051\end{array}$ & 0.323 & 0.929 & $\begin{array}{l}0.828 \text { to } \\
1.041\end{array}$ & 0.206 & 0.997 & $\begin{array}{l}0.966 \text { to } \\
1.028\end{array}$ & 0.828 & 1.005 & $\begin{array}{l}0.973 \text { to } \\
1.039\end{array}$ & 0.751 \\
\hline $\begin{array}{l}\text { Serum C3 level } \\
(\mathrm{mg} / \mathrm{dL})\end{array}$ & 0.973 & $\begin{array}{l}0.931 \text { to } \\
1.018\end{array}$ & 0.237 & 0.978 & $\begin{array}{l}0.934 \text { to } \\
1.025\end{array}$ & 0.354 & 1.001 & $\begin{array}{l}0.986 \text { to } \\
1.017\end{array}$ & 0.850 & 0.996 & $\begin{array}{l}0.980 \text { to } \\
1.013\end{array}$ & 0.658 \\
\hline $\begin{array}{l}\text { Serum C4 level } \\
(\mathrm{mg} / \mathrm{dL})\end{array}$ & 0.955 & $\begin{array}{l}0.873 \text { to } \\
1.044\end{array}$ & 0.312 & 0.950 & $\begin{array}{l}0.865 \text { to } \\
1.044\end{array}$ & 0.288 & 0.989 & $\begin{array}{l}0.947 \text { to } \\
1.032\end{array}$ & 0.609 & 0.976 & $\begin{array}{l}0.931 \text { to } \\
1.023\end{array}$ & 0.319 \\
\hline $\begin{array}{l}\text { Serum } \mathrm{CH} 50 \text { level } \\
\text { (IU/L) }\end{array}$ & 0.962 & $\begin{array}{l}0.900 \text { to } \\
1.028\end{array}$ & 0.255 & 0.959 & $\begin{array}{l}0.893 \text { to } \\
1.031\end{array}$ & 0.255 & 1.000 & $\begin{array}{l}0.976 \text { to } \\
1.025\end{array}$ & 0.989 & 0.995 & $\begin{array}{l}0.968 \text { to } \\
1.022\end{array}$ & 0.696 \\
\hline $\begin{array}{l}\text { Serum CRP level } \\
(\mathrm{mg} / \mathrm{dL})\end{array}$ & 0.157 & $\begin{array}{l}0.002 \text { to } \\
11.902\end{array}$ & 0.402 & 0.005 & $\begin{array}{l}0.000 \text { to } \\
7.321\end{array}$ & 0.154 & 0.810 & $\begin{array}{l}0.475 \text { to } \\
1.381\end{array}$ & 0.439 & 0.903 & $\begin{array}{l}0.530 \text { to } \\
1.540\end{array}$ & 0.708 \\
\hline $\begin{array}{l}\text { Serum } \mathrm{Cr} \text { level } \\
(\mathrm{mg} / \mathrm{dL})\end{array}$ & 0.864 & $\begin{array}{l}0.027 \text { to } \\
27.692\end{array}$ & 0.934 & 0.091 & $\begin{array}{l}0.001 \text { to } \\
12.694\end{array}$ & 0.342 & 1.150 & $\begin{array}{l}0.670 \text { to } \\
1.976\end{array}$ & 0.612 & 1.472 & $\begin{array}{l}0.773 \text { to } \\
2.806\end{array}$ & 0.240 \\
\hline $\begin{array}{l}\text { Eosinophil counts } \\
(100 / \mu \mathrm{L})\end{array}$ & 0.878 & $\begin{array}{l}0.675 \text { to } \\
1.141\end{array}$ & 0.330 & 0.854 & $\begin{array}{l}0.630 \text { to } \\
1.157\end{array}$ & 0.307 & 1.139 & $\begin{array}{l}0.971 \text { to } \\
1.335\end{array}$ & 0.110 & 1.164 & $\begin{array}{l}0.982 \text { to } \\
1.380\end{array}$ & 0.079 \\
\hline $\begin{array}{l}\text { Number of involved } \\
\text { organs }\end{array}$ & 0.827 & $\begin{array}{l}0.393 \text { to } \\
1.744\end{array}$ & 0.619 & 0.825 & $\begin{array}{l}0.372 \text { to } \\
1.830\end{array}$ & 0.635 & 0.889 & $\begin{array}{l}0.654 \text { to } \\
1.209\end{array}$ & 0.454 & 0.930 & $\begin{array}{l}0.665 \text { to } \\
1.301\end{array}$ & 0.672 \\
\hline $\begin{array}{l}\text { IgG4-RD responder } \\
\text { index }\end{array}$ & 1.070 & $\begin{array}{l}0.908 \text { to } \\
1.260\end{array}$ & 0.421 & 1.050 & $\begin{array}{l}0.870 \text { to } \\
1.268\end{array}$ & 0.611 & 0.952 & $\begin{array}{l}0.883 \text { to } \\
1.027\end{array}$ & 0.203 & 0.961 & $\begin{array}{l}0.885 \text { to } \\
1.044\end{array}$ & 0.348 \\
\hline
\end{tabular}

Note: Conversion factor for $\mathrm{Cr}: \mathrm{mg} / \mathrm{dL}$ to $\mu \mathrm{mol} / \mathrm{L}, \times 88.4$.

Abbreviations: ANA, anti-nuclear antibody; Cr, creatinine; CRP, C-reactive protein; IgG, immunoglobulin G; IgG4, immunoglobulin G4; IgE, immunoglobulin E.

\section{Discussion}

The present study, which included patients with various organ involvement mainly salivary gland and ophthalmic lesions, showed that high serum IgG4 levels could be a useful predictor of unfavorable outcomes in untreated patients with IgG4-RD, who tend to have fewer affected organs and lower IgG4-RD responder index than treated patients. These results were different from those in the previous studies showing that new onset of diabetes mellitus and extensive multiorgan involvement were predictors of unfavorable events in untreated patients with AIP [5]. On the other hand, not serum IgG4 levels but the presence of allergic disease was related to deterioration in patients who underwent treatment in this study, consistent with the results of the previous study [11]. Because the natural course without treatment has rarely been evaluated in IgG4-RD except for AIP, these results might provide novel hints to the management of IgG4$\mathrm{RD}$ without treatment and lead to significant advances.

In interpreting the results of the present retrospective study, we need to consider the characteristics of the analyzed untreated patients. Compared with treated patients, untreated ones had significantly lower IgG4-RD responder index and fewer affected organs despite any significant difference in serum IgG4 levels. In the international consensus guidance statement on the management and treatment of IgG4-RD, watchful waiting was described as possibly appropriate in certain patients with asymptomatic and inactive disease [3]. Involvement of multiple organs can be regarded as one indicator of disease activity. Therefore, it seems that decisions regarding treatment initiation were made according to the guidance in the present study. Such decisions, however, resulted in insufficient analysis regarding SI and deterioration of IgG4-RD during the natural clinical course in patients with higher disease activity.

Although spontaneous, or at least temporary, improvement without treatment has been reported in IgG4-RD, its prevalence and predictors remain to be clarified except for AIP. In AIP, it was reported that 55.7-65.0\% of patients experienced SR and absence of serum IgG4 elevation, female gender, and stent placement for jaundice were significantly related to SR $[4,5]$. In the present study in which especially many patients with salivary and ophthalmic lesions were investigated, SI occurred in $6(22.2 \%)$ of the 27 patients and was significantly related not to serum IgG4 levels but to female gender and serum C3 levels. The fact that this significant relationship between SI and female gender in our study was consistent with finding in a previous one [4] suggests that sexual 
differentiation is related to SI irrespective of which organ is involved. The significant relationship noted between SI and serum C3 levels, which were not evaluated in the previous studies [4, 5], indicates that SI is unlikely to occur in patients with hypocomplementemia as a possible indicator of disease activity. Accordingly, a watchful observation without treatment may be appropriate to a certain extent in IgG4-RD patients with these characteristics in addition to asymptomatic and inactive disease.

On the other hand, observation without treatment may impose some degree of risk of irreversible organ dysfunction in IgG4-RD. Recent studies investigating its long-term clinical course have disclosed that dysfunction of affected organs can persist despite glucocorticoid treatment in pancreatic, renal, and salivary gland lesions $[12,13,14,15]$. In addition, such persistent organ dysfunction was reported to be related to existing organ dysfunction at the time of treatment initiation [14] or a long interval between diagnosis and treatment initiation, suggesting that delay of treatment initiation should be avoided. This makes it important to recognize the factors associated with deterioration during observation without treatment in addition to the factors related to SI mentioned above.

The present study showed that history of allergic disease, but not serum IgG4 elevation, was a factor significantly related to deterioration in treated IgG4-RD patients. This is consistent with the results of a recently published study by Liu Y et al. [11] but inconsistent with those of the previous study investigating patients treated with rituximab [16]. On the other hand, interestingly, serum IgG4 elevation was the sole factor associated with deterioration in untreated patients in this study. A positive correlation between serum IgG4 levels and number of affected organs $[17,18]$ suggests that such untreated patients with higher serum IgG4 levels may have clinically silent affected organs and risk of future disease manifestations although whether an early treatment initiation for serum IgG4 elevation without obvious multiple organ manifestations is effective or not needs to be elucidated. More attention should be paid to deterioration of IgG4-RD in cases with high serum IgG4 levels disproportionate to the paucity of involved organs.

This study had several limitations. First, the treatment regimen and follow-up protocols were inconsistent among patients because of its retrospective nature, complicating evaluation of the influence of detailed treatment protocol differences on patient outcome. Second, although this study included more patients with salivary and ophthalmic lesions than past ones, the number of patients was not sufficient to conclude the identified factors to be definitively significant predictors. Therefore, larger-scale prospective studies will be needed to confirm our results.

\section{Conclusions}

The present study suggests that high serum IgG4 levels may be a useful predictor of the unfavorable outcomes of untreated patients with IgG4-RD, who tend to have fewer affected organs and lower IgG4-RD responder index. Although our results need to be confirmed through a larger-scale multicenter prospective study, the present observations may help to establish the optimal management strategy for IgG4-RD and in particular prevent treatment delay in untreated patients.

\section{Abbreviations}

AIP, autoimmune pancreatitis; ANA, anti-nuclear antibodies; CDC, comprehensive diagnostic criteria; $\mathrm{Cl}$, confidence interval; CRP, C-reactive protein; IgE, immunoglobulin E; IgG, immunoglobulin G; IgG4, immunoglobulin G4; IQR, interquartile range; IgG4-RD, immunoglobulin G4 (IgG4)-related disease; OR, odds ratio; $\mathrm{RF}$, rheumatoid factor; $\mathrm{SI}$, spontaneous improvement; $\mathrm{SR}$, spontaneous remissions.

\section{Declarations}

\section{Ethical Approval and Consent to participate}

This study received institutional ethics board approval from the Medical Ethics Committee of Kanazawa University, and informed consent for the use of all data and samples was obtained from each patient. We conducted the research in compliance with the Declaration of Helsinki.

\section{Consent for publication}

Not applicable

\section{Competing interests}

The authors declare that they have no competing interests.

\section{Funding}

This work was supported by Health and Labour Sciences Research Grants for the Study of Intractable Diseases from the Ministry of Health, Labor and Welfare, Japan.

\section{Authors' contributions}

I.M. and M.Kawano are responsible for study conception and design. I.M. and M.Kawano contributed to acquisition and interpretation of the data, drafted the manuscript, and revised the manuscript. M.Konishi, H.S., K.S., A.T., T.Z., S.H., K.I., H.F., and K.Y. contributed to acquisition and interpretation of the data and revised the manuscript. The authors have approved the final manuscript for publication and have agreed to be personally accountable for the authors' contributions.

\section{Acknowledgments}


We thank John Gelblum for his critical reading of the manuscript.

\section{Author details}

\section{Ichiro Mizushima}

Department of Rheumatology, Kanazawa University Hospital, 13-1 Takara-machi, Kanazawa, Ishikawa 920-8640, Japan e-mail address: ichiro7753@yahoo.co.jp

\section{Masahiro Konishi}

Department of Rheumatology, Kanazawa University Hospital, 13-1 Takara-machi, Kanazawa, Ishikawa 920-8640, Japan e-mail address: masahiro524.7878@gmail.com

\section{Hajime Sanada}

Department of Rheumatology, Kanazawa University Hospital, 13-1 Takara-machi, Kanazawa, Ishikawa 920-8640, Japan e-mail address: sanadaikon@gmail.com

\section{Kazuyuki Suzuki}

Department of Rheumatology, Kanazawa University Hospital, 13-1 Takara-machi, Kanazawa, Ishikawa 920-8640, Japan e-mail address: kazu5636@yahoo.co.jp

\section{Akari Takeji}

Department of Rheumatology, Kanazawa University Hospital, 13-1 Takara-machi, Kanazawa, Ishikawa 920-8640, Japan e-mail address: akari.w79@gmail.com

\section{Takeshi Zoshima}

Department of Rheumatology, Kanazawa University Hospital, 13-1 Takara-machi, Kanazawa, Ishikawa 920-8640, Japan e-mail address: takeshiz1983@yahoo.co.jp

\section{Satoshi Hara}

Department of Rheumatology, Kanazawa University Hospital, 13-1 Takara-machi, Kanazawa, Ishikawa 920-8640, Japan e-mail address: satoshy57@hotmail.com

\section{Kiyoaki Ito}

Department of Rheumatology, Kanazawa University Hospital, 13-1 Takara-machi, Kanazawa, Ishikawa 920-8640, Japan e-mail address: kiyokiyo1980fukui@yahoo.co.jp

\section{Hiroshi Fujii}

Department of Rheumatology, Kanazawa University Hospital, 13-1 Takara-machi, Kanazawa, Ishikawa 920-8640, Japan e-mail address: hiroshi_fujii76@yahoo.co.jp

\section{Kazunori Yamada}

Department of Rheumatology, Kanazawa University Hospital, 13-1 Takara-machi, Kanazawa, Ishikawa 920-8640, Japan e-mail address: kyamada50@yahoo.co.jp

\section{Mitsuhiro Kawano}

Department of Rheumatology, Kanazawa University Hospital, 13-1 Takara-machi, Kanazawa, Ishikawa 920-8640, Japan e-mail address: sk33166@gmail.com 
The data underlying this article will be shared on reasonable request to the corresponding author.

The results presented in this paper have not been published previously in whole or part, except in abstract format.

\section{References}

1. Stone JH, Zen Y, Deshpande V. IgG4-related disease. N Engl J Med 2012;366:539-51.

2. Umehara H, Okazaki K, Masaki Y et al. A novel clinical entity, IgG4-related disease (IgG4RD): general concept and details. Mod Rheumatol 2012;22:1-14.

3. Khosroshahi A, Wallace ZS, Crowe JL, Akamizu T, Azumi A, Carruthers MN, Chari ST, Della-Torre E, Frulloni L, Goto H, Hart PA, Kamisawa T, Kawa S, Kawano M, Kim MH, Kodama Y, Kubota K, Lerch MM, Löhr M, Masaki Y, Matsui S, Mimori T, Nakamura S, Nakazawa T, Ohara H, Okazaki K, Ryu JH, Saeki T, Schleinitz N, Shimatsu A, Shimosegawa T, Takahashi H, Takahira M, Tanaka A, Topazian M, Umehara H, Webster GJ, Witzig TE, Yamamoto M, Zhang W, Chiba T, Stone JH; Second International Symposium on IgG4-Related Disease. International Consensus Guidance Statement on the Management and Treatment of IgG4-Related Disease. Arthritis Rheumatol. 2015;67:1688-99.

4. Kubota K, Watanabe S, Uchiyama T, Kato S, Sekino Y, Suzuki K, Mawatari H, lida H, Endo H, Fujita K, Yoneda M, Takahashi H, Kirikoshi H, Kobayashi N, Saito S, Sugimori K, Hisatomi K, Matsuhashi N, Sato H, Tanida E, Sakaguchi T, Fujisawa N, Nakajima A, et al. Factors predictive of relapse and spontaneous remission of autoimmune pancreatitis patients treated/not treated with corticosteroids. J Gastroenterol. 2011;46:834-42.

5. Kubota K, Kamisawa T, Hirano K, Hirooka Y, Uchida K, Ikeura T, Shiomi H, Ohara H, Shimizu K, Arakura N, Kanno A, Sakagami J, Itoi T, Ito T, Ueki T, Nishino T, Inui K, Mizuno N, Yoshida H, Sugiyama M, Iwasaki E, Irisawa A, Okazaki K, Kawa S, Shimosegawa T, Takeyama Y, Chiba T, et al. Clinical course of type 1 autoimmune pancreatitis patients without steroid treatment $\rrbracket a$ Japanese multicenter study of 97 patients. J Hepatobiliary Pancreat Sci. 2018;25:22330.

6. Hirano K, Tada M, Isayama H, Yagioka H, Sasaki T, Kogure H, Nakai Y, Sasahira N, Tsujino T, Yoshida H, Kawabe T, Omata M, et al. Long-term prognosis of autoimmune pancreatitis with and without corticosteroid treatment. 2007;56:1719-24.

7. Umehara H, Okazaki K, Masaki Y, Kawano M, Yamamoto M, Saeki T, Matsui S, Yoshino T, Nakamura S, Kawa S, Hamano H, Kamisawa T, Shimosegawa T, Shimatsu A, Nakamura S, Ito T, Notohara K, Sumida T, Tanaka Y, Mimori T, Chiba T, Mishima M, Hibi T, Tsubouchi H, Inui K, Ohara H et al. Comprehensive diagnostic criteria for IgG4-related disease (IgG4-RD), 2011. Mod Rheumatol 2012;22:21-30.

8. Masaki Y, Sugai S, Umehara H. IgG4-related diseases including Mikulicz's disease and sclerosing pancreatitis: diagnostic insights. J Rheum 2010;37:1380-5

9. Okazaki K, Kawa S, Kamisawa T, Ito T, Inui K, Irie H, Nishino T, Notohara K, Nishimori I, Tanaka S, Nishiyama T, Suda K, Shiratori K, Tanaka M, Shimosegawa T et al. Amendment of the Japanese Consensus Guidelines for Autoimmune Pancreatitis, $2013 \mathrm{I}$. Concept and diagnosis of autoimmune pancreatitis. J Gastroenterol 2014;49:567-88.

10. Kawano M, Saeki T, Nakashima H, Nishi S, Yamaguchi Y, Hisano S, Yamanaka N, Inoue D, Yamamoto M, Takahashi H, Nomura H, Taguchi T, Umehara H, Makino H, Saito T et al. Proposal for diagnostic criteria for IgG4-related kidney disease. Clin Exp Nephrol 2011;15:615-26.

11. Liu Y, Zeng Q, Zhu L, Gao J, Wang Z, Wang Z, Yang F, Wang K, Chen D, Xia C, Zhang S, Wang Y, Shen D, Yu G, Li ZG et al. Relapse predictors and serologically unstable condition of IgG4-related disease: a large Chinese cohort. Rheumatology (Oxford). 2020;59:2115-23.

12. Maire F, Le Baleur Y, Rebours V, Vullierme MP, Couvelard A, Voitot H, Sauvanet A, Hentic O, Lévy P, Ruszniewski P, Hammel P, et al. Outcome of patients with type 1 or 2 autoimmune pancreatitis. Am J Gastroenterol. 2011;106:151-6.

13. Maruyama M, Watanabe T, Kanai K, Oguchi T, Asano J, Ito T, Ozaki Y, Muraki T, Hamano H, Arakura N, Kawa S, et al. Autoimmune pancreatitis can develop into chronic pancreatitis. Orphanet J Rare Dis 2014;9:77.

14. Mizushima I, Yamamoto M, Inoue D, Nishi S, Taniguchi Y, Ubara Y, Matsui S, Yasuno T, Nakashima H, Takahashi H, Yamada K, Nomura H, Yamagishi M, Saito T, Kawano M, et al. Factors related to renal cortical atrophy development after glucocorticoid therapy in IgG4-related kidney disease: a retrospective multicenter study. Arthritis Res Ther. 2016;18:273.

15. Shimizu Y, Yamamoto M, Naishiro Y, Sudoh G, Ishigami K, Yajima H, Tabeya T, Matsui M, Suzuki C, Takahashi H, Seki N, Himi T, Yamashita K, Noguchi H, Hasegawa T, Suzuki Y, Honda S, Abe T, Imai K, Shinomura Y, et al. Necessity of early intervention for IgG4-related disease-delayed treatment induces fibrosis progression. Rheumatology (Oxford). 2013;52:679-83.

16. Wallace ZS, Mattoo H, Mahajan VS, Kulikova M, Lu L, Deshpande V, Choi HK, Pillai S, Stone JH, et al. Predictors of disease relapse in IgG4-related disease following rituximab. Rheumatology (Oxford) 2016;55:1000-8.

17. Inoue D, Yoshida K, Yoneda N, Ozaki K, Matsubara T, Nagai K, Okumura K, Toshima F, Toyama J, Minami T, Matsui O, Gabata T, Zen Y, et al. IgG4-related disease: dataset of 235 consecutive patients. Medicine (Baltimore). 2015;94:e680. 
18. Wallace ZS, Deshpande V, Mattoo H, Mahajan VS, Kulikova M, Pillai S, Stone JH, et al. IgG4-Related Disease: Clinical and Laboratory Features in One Hundred Twenty-Five Patients. Arthritis Rheumatol. 2015;67:2466-75. 